\title{
DEVELOPMENT OF AN INDEX FOR EVALUATING NATIONAL QUALITY COMPETITIVENESS BASED ON WEF AND IMD COMPILED INDICES
}

\author{
DOI: 10.12776/QIP.V18I1.319
}

\author{
INSU CHO, KIWON LEE, HEEJUN PARK, MYUNGHO PARK, \\ JOSEPH KICHUL KIM
}

\author{
Received 12 May 2014, Revised 7 June 2014, Accepted 10 June 2014
}

\section{INTRODUCTION}

Globalization, rapid technical change, and shrinking economic distance are presenting newer challenges that change constantly causing stressful competitive environments (Lall, 2001). Meaningful attempts undoubtedly have been made to cope with this situation, including the creation of competitiveness indices that serve to evaluate and improve performance when national or international organizations implement their policies. For instance, international organizations such as the World Economic Forum (WEF) and the International Institute for Management Development (IMD) have developed and disseminated standard indices that help in evaluating and comparing the level of advancement and capabilities among countries (Cho and Moon, 2005). These indices are used not only as data for simple analyses but also as a reference data when countries must create pertinent policies. These indices also have considerable effects on the real economy.

Contrasted with research about national competitiveness, the current understanding of quality competitiveness is still inadequate, in part due to the lack of detailed indicators for measurement and management of quality. Also, businesses operating beyond their national boundaries cannot depend upon previously proven domestic quality practices (Mehra and Agrawal, 2003). Therefore, it is necessary to revise and manage its quality-based elements of competitive strategy in national level (Mehra and Agrawal, 2003).

This study presents a new index of national quality competitiveness based on the national competitiveness indices created by the world's leading organizations. The national quality competitiveness index (NQCI) offers three advantages. First, NQCI allows countries to identify the status of their national quality and provide a systematic policy direction. Second, NQCI helps carry out efficient index 
management by focusing their capabilities on the critical factors. Finally, as this index will continually be based on annual data by the WEF and IMD it helps countries to acquire data with ease and ensure the sustainability of their NQCI.

The following sections of this study comprises of four chapters. In Chapter 2 , national quality competitiveness is defined and the criteria with which to select the quality competitiveness index are identified based on a review of previous studies and future trend reports. In Chapter 3 , the WEF and IMD, which provide the raw data for quality competitiveness indices are reviewed. Based on the analysis of the WEF and IMD, we select the indicators for the NQCI and present statistical verifications to determine the validity of the NQCI. In Chapter 4, the NQCI is implemented in the target countries and its practicality is examined. Lastly, Chapter 5 addresses the implications of the NQCI.

\section{FRAMEWORK OF QUALITY COMPETITIVENESS}

\subsection{Definition of quality competitiveness}

Although quality management and national competitiveness have been researched from various perspectives, the term, national quality competitiveness is rather unfamiliar. This section helps clarify the concepts of quality and competitiveness and presents a definition of national quality competitiveness.

\section{Quality}

Because quality is considered one of the most important factors behind a company's economic growth (Feigenbaum, 1982), many studies related to quality have been undertaken (Reeves and Bednar, 1994). Buzzell and Gale (1987) as well as Gronroos (1990) defined quality as the extent to which a product or service fulfils or exceeds the expectations of the customer. Moreover, the concept of quality tends to be applied to all functions within a company, including marketing, $\mathrm{R} \& \mathrm{D}$, accounting, production, transportation, and distribution/logistics (Blackiston, 1996).

As described above, the definition of quality has expanded to accommodate the changing business circumstances and the demands of the times. Therefore, quality should be understood as a universal concept and not pigeonholed into a specific sector, industry or function (Reeves and Bednar, 1994; Juran, 1988).

\section{National competitiveness}

Some studies define national competitiveness as a critical factor that determines company's competitiveness. In these studies, the government's roles must include supporting companies in their effort to sustain competitiveness (Porter, 1998; Tyson, 1993). In a similar vein, the IMD defines competitiveness as a country's abilities to create and maintain conditions that help companies sustain their competitiveness (Garelli, 2006). The WEF defines competitiveness as government's policies, rules and regulations that allow continued economic growth and long-term prosperity (Schwab, 2010). 
This study also acknowledges the need for governmental intervention in the matter of quality. Thus, the concept of competitiveness is applied here with a focus shifted from the roles of businesses to those of government.

\section{National quality competitiveness}

Combining the aforesaid definitions of 'quality' and 'national competitiveness,' this study presents a definition of 'national quality competitiveness' that suits the research purpose: A country's competencies involve creating and maintaining conditions under which the quality of products and services can satisfy the expectations of interested parties and in which this state of satisfaction can be sustained.

\subsection{Critical factors in quality competitiveness}

A large number of researchers have suggested factors for quality management striving to find criteria and principles. For instance, Saraph, Benson and Schroeder (1989) conducted an extensive literature review on the principles that are related to conventional quality management practices. Based on their review, they identified and analysed eight categories: top management support, quality information availability, quality information usage, employee training, employee involvement, product/process design, supplier quality, and customer orientation. Porter and Parker (1993) also undertook a similar empirical study, proposing eight critical factors: management behaviour, strategy, organization, communication, training, employee involvement, process and systems, and quality technologies.

Black and Porter (1996), on the other hand, devised 10 critical factors by incorporating the criteria of the Malcolm Baldrige National Quality Award: people and customer management, supplier partnerships, communication of improvement information, customer satisfaction orientation, external interface management, strategic quality management, teamwork structures for improvement, operational quality planning, quality improvement measurement systems, and the corporate quality culture. Black and Porter (1996) proposed that their proposed factors were more realistic and were adaptable to the fastchanging market environment.

Based on the critical factors proposed by previous studies, this study presents its own five critical factors: leadership for quality, support from the internal work force, the relationship with the external environment, customer orientation, and continuous improvement. First, leadership for quality establishes the orientation and criteria of the programs aiming at an improvement in quality competitiveness. Second, concerning support from the internal work force, education/training and compensation are offered to help promote the spontaneous cooperation and participation of the internal personnel. Third, in relationship to the external environment, an amicable relationship is formed with interested parties involved in quality competitiveness improvement efforts (e.g., suppliers, governments). Fourth, for customer orientation, the focus of quality competitiveness is placed on the customer's expectations and degree of 
satisfaction. Lastly, regarding continuous improvement, effort is made to ensure appropriate responses to the ever-changing environment as well as continuous improvement and advancement.

\subsection{Analysis of global trends}

Trend analysis reports published by several prominent research institutes were examined to identify issues related to quality.

Global Trends, a report published every four years by the US-based National Intelligence Council, is analysed by government agencies as well as the world's leading academic and specialized research institutions. They conduct research in the following seven areas: the global economy; global demographic trends; international politics; energy, food and resource issues; regional conflicts; international systems; and leadership (Fingar, 2009). Table 1 summarizes the key words and main points of the Global Trends 2025 report.

Table 1 - Global Trends 2025

\begin{tabular}{ll} 
Key Word & Global Trend 2025 \\
\hline $\begin{array}{l}\text { The Globalizing } \\
\text { Economy }\end{array}$ & $\begin{array}{l}\text { Back to the Future } \\
\text { Bumpy Ride in Correction Current Global Imbalance }\end{array}$ \\
$\begin{array}{l}\text { The Demographics } \\
\text { of Discord }\end{array}$ & $\begin{array}{l}\text { Populations Growing, Declining, and Diversifying-at the same time } \\
\text { The Pensioner Boom: Challenges of Aging Populations }\end{array}$ \\
The New Players & $\begin{array}{l}\text { Rising Heavy weights: China and India } \\
\text { Other Key Payers }\end{array}$ \\
$\begin{array}{l}\text { Scarcity in the Midst } \\
\text { of Plenty }\end{array}$ & $\begin{array}{l}\text { The Dawning of a Post-Petroleum Age? } \\
\text { Water, Food, and Climate Change }\end{array}$ \\
$\begin{array}{l}\text { Growing Potential } \\
\text { for Conflict }\end{array}$ & $\begin{array}{l}\text { Growing Risk of a Nuclear Arms Race in the Middle East } \\
\text { Terrorism: Good and Bad News }\end{array}$ \\
International System & $\begin{array}{l}\text { Multipolarity without Multilateralism } \\
\text { How Many International Systems? }\end{array}$ \\
$\begin{array}{l}\text { Power-sharing in a } \\
\text { Multipolar World }\end{array}$ & $\begin{array}{l}\text { New Relationships and Recalibrated Old Partnerships } \\
\text { Less Financial Margin of Error }\end{array}$ \\
\hline
\end{tabular}

Secondly, Tracking Global Trends, an annual report by the global financial and management consulting services company Ernst \& Young (2010), publishes forecasts for the world economy. Ernst \& Young published in 2010 'Business 2020: a Futurizon report', suggesting six global trends. Table 2 lists the main points and key words of the proposed trends. 
Table 2 - Key Words and Main Points of Six Global Trends

\begin{tabular}{ll}
\hline Key Word & 6 Global Trends \\
\hline Rise of emerging markets & $\begin{array}{l}\text { Emerging markets increase their global power } \\
\text { Cleantech for climate }\end{array}$ \\
$\begin{array}{l}\text { The transformed financial landscape } \\
\text { Increased role of government }\end{array}$ & $\begin{array}{l}\text { Global banking seeks recovery through } \\
\text { transformation }\end{array}$ \\
The next evolution of technology & $\begin{array}{l}\text { Governments enhance ties with the private sector } \\
\text { world }\end{array}$ \\
Movement of the global workforce & Demographic shifts transform the global workforce \\
\hline
\end{tabular}

Based on the examination of trend-analysis reports, this study identified four quality issues that are appropriate for the national quality competitiveness. The first issue identified is global management. This involves issues such as globalization and the global economy, all of which require companies and countries to embrace a new quality management. Second, environmental and energy crises are raising the need for the industries to 'go green'. Thus, this issue demands directions for quality improvements that take environmental and energy issues into account as regards challenging tasks such as the depletion of fossil fuels, pollution, and climate change. The third issue, technological innovation, is becoming increasingly important with the advent of the industrial convergence era, the acceleration of technological evolution, and the active integration between technologies. Lastly, socio-cultural emphasis is placed on the increased value of individuals. As the importance of this value is rising, consumer behaviour is changing, personal values are becoming refined, and the value of culture is increasing. These changes require that personal/individual values be taken into account when dealing with quality.

\section{NATIONAL QUALITY COMPETITIVENESS INDEX (NQCI)}

The study was conducted primarily to devise a quality competitiveness index that can be compared and utilized at the national level. To that end, an analysis was conducted of reports published in the WEF and IMD both of which enjoy public confidence. Based on the analysis, indices were selected and subjected to statistical tests such as factor analysis and cluster analysis. Using the statistical data, a national quality competitiveness index (NQCI) was developed. 


\subsection{Competitiveness index analysis based on WEF and IMD data}

To develop the NQCI, the World Economic Forum (WEF) and International Institute for Management Development (IMD) data were used as the material for the analysis because they are open source data that are available to the public. Moreover, these indices are recognized internationally as reliable national competitiveness indices therefore ensuring the validity of the NQCI. The WEF publishes the Global Competitiveness Report (GCR), an annual report that factors constituting a national economy so as to help ensure sustainable economic growth and long-term prosperity. Since 2005, the forum has issued the Global Competitiveness Index (GCI), a comprehensive index that measures countries' national competitiveness. These reports include the countries' microeconomic and macroeconomic data (Schwab, 2009).

The GCI consists of about 110 indicators spread out in 12 pillars in three areas, as shown in Figure 1. It is being complied for nearly 130 countries. Some pillars are related to the critical factors for quality competitiveness and global quality trends that were mentioned earlier in this paper. Examples of the pillars are: business sophistication, related to global management; innovation, related to interoperation between sectors/industries and the response to environmental changes; good market efficiency, labor market efficiency, financial market sophistication and technological readiness, all factors affect quality improvement, such as competitors, suppliers, customers, the work force, the government, technology, and the financial market; and infrastructure, the foundation on which competitiveness-related activities take place. The excellence of GCI is particularly noted in the microeconomic issues (Lall, 2001).

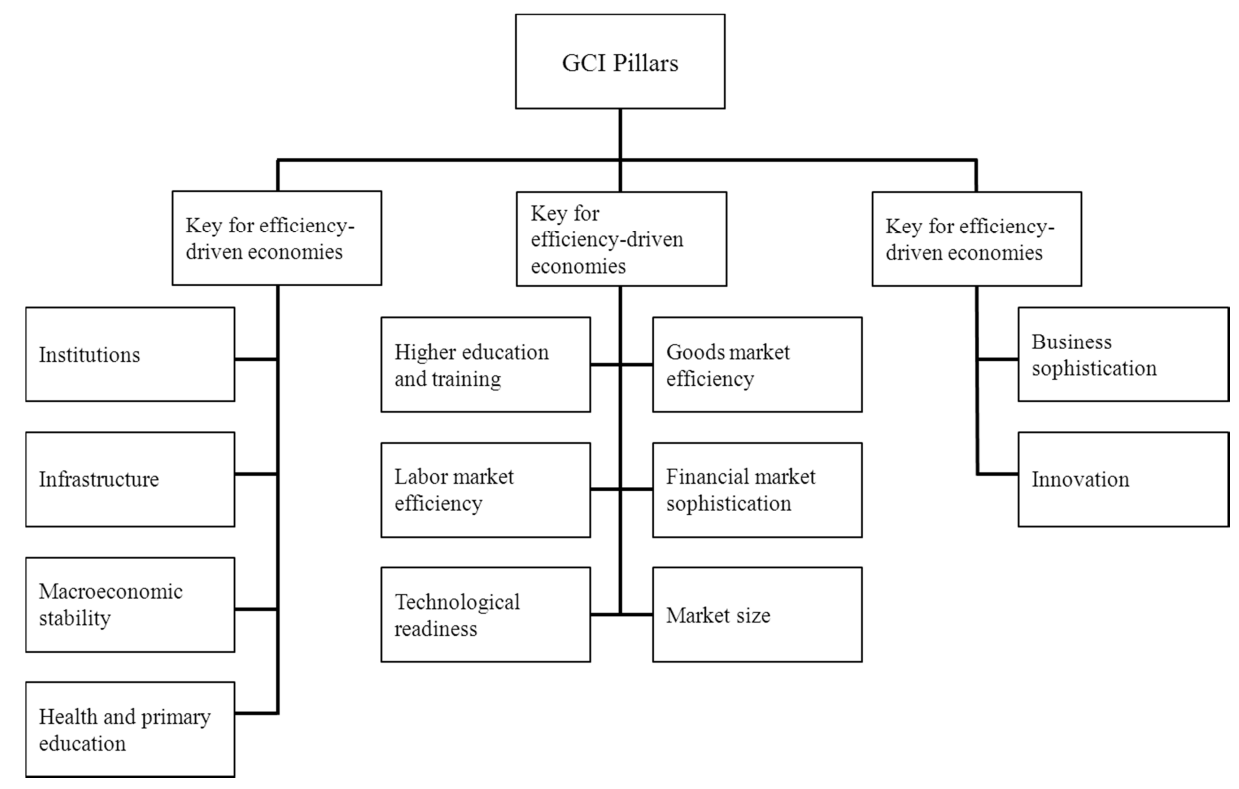

Figure 1 - The 12 pillars of competitiveness 
The IMD publishes the World Competitiveness Yearbook (WCY), an annual report that analyses how the environment of some 58 countries affects the creation and maintenance of their respective degrees of corporate competitiveness. It also determines the ranking of the countries according to the analysis. The WCY consists of some 330 indicators in 20 pillars in four areas, as shown in Figure 2. The WCY presents criteria associated with the quality competitiveness factors and global quality trends. The criteria are the technological infrastructure and the scientific infrastructure, providing input sources to ensure continuous quality improvement; and health and the environment, indicating the direction of quality improvement in terms of energy and environmental conservation. They also include the labour market, allowing the measurement of internal parties' competitiveness; management practices, showing a company's sustainable capabilities and its leaders' quality policies; and basic infrastructure and finance, indicating the level of factors behind quality improvement.

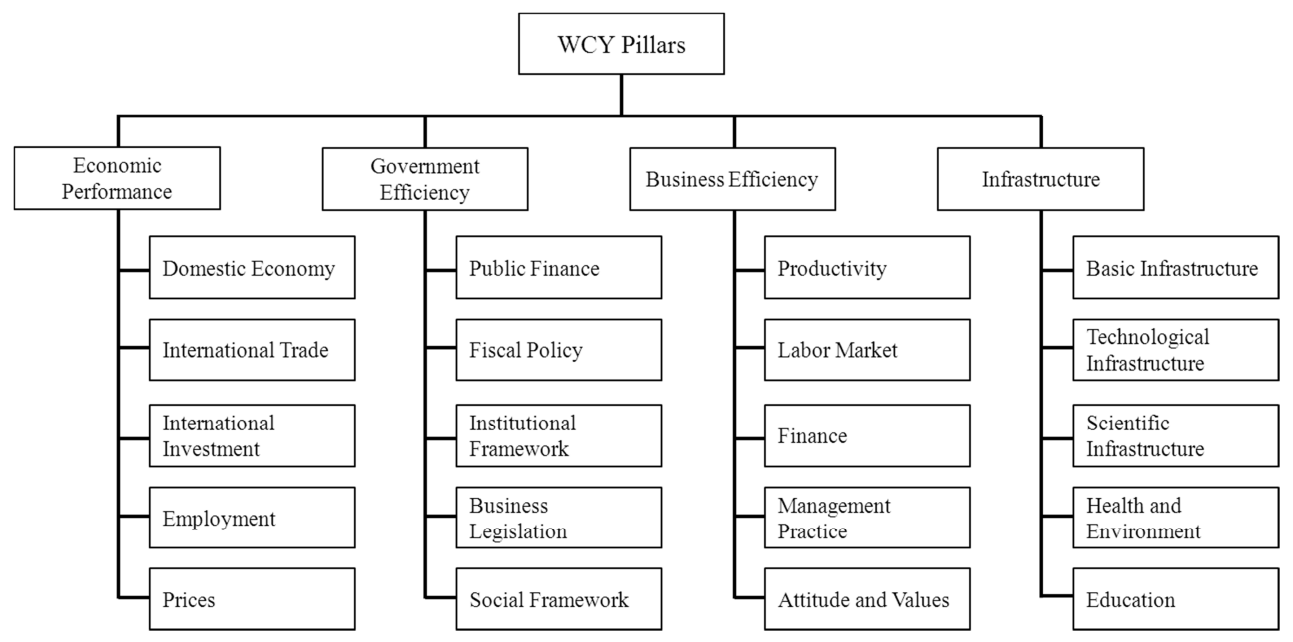

Figure 2 - Four pillars of competitiveness

The GCI and WCY factors/criteria, however, are not without shortcomings. The GCI materials rely heavily on data gathered from surveys and have a complicated weighted value system when it comes to technology, public agencies, and the macroeconomic environment. The WCY, on the other hand, introduces a greater variety of competitiveness evaluation factors compared to the GCI. However, its system comprises only four pillars and uses a simple totalling technique, which weakens its theoretical foundation. Furthermore, the WCY materials have problems such as frequent changes in its evaluation model and a lack of consistency in its partnered investigation agencies. Therefore, it appears necessary to take the strengths of the GCI and WCY factors/indicators and combine them effectively to offset the shortcomings. 


\subsection{Selection of indicators}

First, based on five critical factors for quality competitiveness and four global quality trends, 25 indicators were selected from the WEF materials, as shown in Table 3.

Table 3 - Indicators Selected from the WEF Materials

\begin{tabular}{|c|c|c|c|c|}
\hline \multirow[b]{2}{*}{ Index } & \multirow[b]{2}{*}{ Pillar } & \multirow[b]{2}{*}{ Indicators } & \multicolumn{2}{|l|}{ Criteria } \\
\hline & & & $\begin{array}{l}\text { Critical factor for } \\
\text { quality competitiveness }\end{array}$ & Global trend \\
\hline W1 & Institution & $\begin{array}{l}\text { Ethical behaviour } \\
\text { of firms }\end{array}$ & Leadership for quality & \\
\hline W2 & Infrastructure & $\begin{array}{l}\text { Quality of overall } \\
\text { infrastructure }\end{array}$ & Continuous improvement & $\begin{array}{l}\text { Global } \\
\text { management }\end{array}$ \\
\hline W3 & $\begin{array}{l}\text { Higher education } \\
\text { and training }\end{array}$ & $\begin{array}{l}\text { Quality of the } \\
\text { educational system }\end{array}$ & $\begin{array}{l}\text { Support from the internal } \\
\text { work force }\end{array}$ & \\
\hline W4 & $\begin{array}{l}\text { Goods market } \\
\text { efficiency }\end{array}$ & $\begin{array}{l}\text { Intensity of local } \\
\text { competition }\end{array}$ & $\begin{array}{l}\text { Relationship with the } \\
\text { external environment }\end{array}$ & \\
\hline W5 & & $\begin{array}{l}\text { Degree of customer } \\
\text { orientation }\end{array}$ & Customer orientation & $\begin{array}{l}\text { Individual } \\
\text { values }\end{array}$ \\
\hline W6 & & $\begin{array}{l}\text { Buyer } \\
\text { sophistication }\end{array}$ & $\begin{array}{l}\text { Relationship with the } \\
\text { external environment }\end{array}$ & \\
\hline W7 & $\begin{array}{l}\text { Labour market } \\
\text { efficiency }\end{array}$ & $\begin{array}{l}\text { Cooperation in } \\
\text { labour-employer } \\
\text { relations }\end{array}$ & $\begin{array}{l}\text { Support from the internal } \\
\text { work force }\end{array}$ & \\
\hline W8 & & $\begin{array}{l}\text { Hiring and firing } \\
\text { practices }\end{array}$ & $\begin{array}{l}\text { Support from the internal } \\
\text { work force }\end{array}$ & \\
\hline W9 & $\begin{array}{l}\text { Financial market } \\
\text { sophistication }\end{array}$ & $\begin{array}{l}\text { Financial market } \\
\text { sophistication }\end{array}$ & $\begin{array}{l}\text { Relationship with the } \\
\text { external environment }\end{array}$ & \\
\hline W10 & & $\begin{array}{l}\text { Venture capital } \\
\text { availability }\end{array}$ & $\begin{array}{l}\text { Relationship with the } \\
\text { external environment }\end{array}$ & \\
\hline W11 & $\begin{array}{l}\text { Technological } \\
\text { readiness }\end{array}$ & $\begin{array}{l}\text { Availability of } \\
\text { latest technologies }\end{array}$ & & $\begin{array}{l}\text { Global } \\
\text { management }\end{array}$ \\
\hline W12 & & $\begin{array}{l}\text { Firm-level technology } \\
\text { absorption }\end{array}$ & & $\begin{array}{l}\text { Technological } \\
\text { innovation }\end{array}$ \\
\hline W13 & $\begin{array}{l}\text { Business } \\
\text { sophistication }\end{array}$ & $\begin{array}{l}\text { Local supplier } \\
\text { quantity }\end{array}$ & $\begin{array}{l}\text { Relationship with the } \\
\text { external environment }\end{array}$ & \\
\hline W14 & & $\begin{array}{l}\text { Local supplier } \\
\text { quality }\end{array}$ & $\begin{array}{l}\text { Relationship with the } \\
\text { external environment }\end{array}$ & \\
\hline W15 & & $\begin{array}{l}\text { Nature of competitive } \\
\text { advantage }\end{array}$ & & $\begin{array}{l}\text { Global } \\
\text { management }\end{array}$ \\
\hline W16 & & $\begin{array}{l}\text { Control of } \\
\text { international } \\
\text { distribution }\end{array}$ & $\begin{array}{l}\text { Relationship with the } \\
\text { external environment }\end{array}$ & $\begin{array}{l}\text { Global } \\
\text { management }\end{array}$ \\
\hline
\end{tabular}




\begin{tabular}{|c|c|c|c|c|}
\hline \multirow[b]{2}{*}{ Index } & \multirow[b]{2}{*}{ Pillar } & \multirow[b]{2}{*}{ Indicators } & \multicolumn{2}{|l|}{ Criteria } \\
\hline & & & $\begin{array}{l}\text { Critical factor for } \\
\text { quality competitiveness }\end{array}$ & Global trend \\
\hline W17 & & $\begin{array}{l}\text { Production process } \\
\text { sophistication }\end{array}$ & & $\begin{array}{l}\text { Global } \\
\text { management }\end{array}$ \\
\hline W18 & & Extent of marketing & $\begin{array}{l}\text { Relationship with the } \\
\text { external environment }\end{array}$ & $\begin{array}{l}\text { Global } \\
\text { management }\end{array}$ \\
\hline W19 & Innovation & $\begin{array}{l}\text { Capacity for } \\
\text { innovation }\end{array}$ & Continuous improvement & $\begin{array}{l}\text { Technological } \\
\text { innovation }\end{array}$ \\
\hline W20 & & $\begin{array}{l}\text { Quality of scientific } \\
\text { research institutions }\end{array}$ & & $\begin{array}{l}\text { Technological } \\
\text { innovation }\end{array}$ \\
\hline W21 & & $\begin{array}{l}\text { Company spending } \\
\text { on } R \& D\end{array}$ & & $\begin{array}{l}\text { Technological } \\
\text { innovation }\end{array}$ \\
\hline W22 & & $\begin{array}{l}\text { University-industry } \\
\text { collaboration in R\&D }\end{array}$ & $\begin{array}{l}\text { Relationship with the } \\
\text { external environment }\end{array}$ & $\begin{array}{l}\text { Technological } \\
\text { innovation }\end{array}$ \\
\hline W23 & & $\begin{array}{l}\text { Government } \\
\text { procurement of } \\
\text { advanced tech products }\end{array}$ & $\begin{array}{l}\text { Relationship with the } \\
\text { external environment }\end{array}$ & \\
\hline W24 & & $\begin{array}{l}\text { Availability of } \\
\text { scientists and engineers }\end{array}$ & $\begin{array}{l}\text { Relationship with the } \\
\text { external environment }\end{array}$ & \\
\hline W25 & & Utility patents & & $\begin{array}{l}\text { Technological } \\
\text { innovation }\end{array}$ \\
\hline
\end{tabular}

Next, using the IMD's factors, several indicators were chosen from the aforementioned six pillars. Some indicators were also selected from the pillars of 'economic performance' and 'government efficiency' based on five critical factors for quality competitiveness and four global quality trends. Table 4 lists the final 26 indicators selected

Table 4 - Indicators Selected from the IMD Materials

\begin{tabular}{|c|c|c|c|c|}
\hline \multirow[b]{2}{*}{ Index } & \multirow[b]{2}{*}{ Pillar } & \multirow[b]{2}{*}{ Indicators } & \multicolumn{2}{|l|}{ Criteria } \\
\hline & & & $\begin{array}{l}\text { Critical factor for } \\
\text { quality competitiveness }\end{array}$ & Global trend \\
\hline I1 & $\begin{array}{l}\text { Management } \\
\text { Practice }\end{array}$ & Ethical practices & Leadership for quality & \\
\hline $\mathrm{I} 2$ & $\begin{array}{l}\text { Basic } \\
\text { Infrastructure }\end{array}$ & $\begin{array}{l}\text { Distribution } \\
\text { infrastructure }\end{array}$ & & $\begin{array}{l}\text { Global } \\
\text { management }\end{array}$ \\
\hline I3 & & Energy infrastructure & & $\begin{array}{l}\text { Environmental } \\
\text { and energy crises }\end{array}$ \\
\hline I4 & Education & Educational system & $\begin{array}{l}\text { Support from the } \\
\text { internal work force }\end{array}$ & \\
\hline
\end{tabular}




\begin{tabular}{|c|c|c|c|c|}
\hline \multirow[b]{2}{*}{ Index } & \multirow[b]{2}{*}{ Pillar } & \multirow[b]{2}{*}{ Indicators } & \multicolumn{2}{|l|}{ Criteria } \\
\hline & & & $\begin{array}{l}\text { Critical factor for } \\
\text { quality competitiveness }\end{array}$ & Global trend \\
\hline I5 & $\begin{array}{l}\text { Scientific } \\
\text { Infrastructure }\end{array}$ & Science degrees & & $\begin{array}{l}\text { Technological } \\
\text { innovation }\end{array}$ \\
\hline I6 & $\begin{array}{l}\text { Management } \\
\text { Practice }\end{array}$ & $\begin{array}{l}\text { Customer } \\
\text { satisfaction }\end{array}$ & Customer orientation & \\
\hline I7 & Labour Market & Labour relations & $\begin{array}{l}\text { Support from the } \\
\text { internal work force }\end{array}$ & \\
\hline I8 & $\begin{array}{l}\text { Business } \\
\text { Legislation }\end{array}$ & Labour regulations & $\begin{array}{l}\text { Support from the } \\
\text { internal work force }\end{array}$ & \\
\hline I9 & Finance & $\begin{array}{l}\text { Banking and } \\
\text { financial services }\end{array}$ & $\begin{array}{l}\text { Relationship with the } \\
\text { external environment }\end{array}$ & \\
\hline $\mathrm{I} 10$ & & Venture capital & $\begin{array}{l}\text { Relationship with the } \\
\text { external environment }\end{array}$ & \\
\hline I11 & $\begin{array}{l}\text { Management } \\
\text { Practice }\end{array}$ & $\begin{array}{l}\text { Adaptability of } \\
\text { companies }\end{array}$ & Leadership for quality & \\
\hline $\mathrm{I} 12$ & $\begin{array}{l}\text { Scientific } \\
\text { Infrastructure }\end{array}$ & Innovative capacity & & $\begin{array}{l}\text { Technological } \\
\text { innovation }\end{array}$ \\
\hline $\mathrm{I} 13$ & & $\begin{array}{l}\text { Business expenditure } \\
\text { on } R \& D(\$)\end{array}$ & & $\begin{array}{l}\text { Technological } \\
\text { innovation }\end{array}$ \\
\hline I14 & & $\begin{array}{l}\text { Business expenditure } \\
\text { on R\&D (\% of GDP) }\end{array}$ & & $\begin{array}{l}\text { Technological } \\
\text { innovation }\end{array}$ \\
\hline $\mathrm{I} 15$ & & Knowledge transfer & $\begin{array}{l}\text { Support from the } \\
\text { internal work force }\end{array}$ & $\begin{array}{l}\text { Global } \\
\text { management }\end{array}$ \\
\hline I16 & & $\begin{array}{l}\text { Number of patents in } \\
\text { force }\end{array}$ & & $\begin{array}{l}\text { Technological } \\
\text { innovation }\end{array}$ \\
\hline I17 & Labour Market & Employee training & $\begin{array}{l}\text { Support from the } \\
\text { internal work force }\end{array}$ & \\
\hline $\mathrm{I} 18$ & $\begin{array}{l}\text { Management } \\
\text { Practice }\end{array}$ & Social responsibility & Leadership for quality & \\
\hline I19 & $\begin{array}{l}\text { Technological } \\
\text { Infrastructure } \\
\text { Innovation }\end{array}$ & $\begin{array}{l}\text { Development and } \\
\text { application of } \\
\text { technology }\end{array}$ & $\begin{array}{l}\text { Continuous } \\
\text { improvement }\end{array}$ & $\begin{array}{l}\text { Technological } \\
\text { innovation }\end{array}$ \\
\hline $\mathrm{I} 20$ & & $\begin{array}{l}\text { Communications } \\
\text { technology }\end{array}$ & & $\begin{array}{l}\text { Global } \\
\text { management }\end{array}$ \\
\hline $\mathrm{I} 21$ & & Qualified engineers & & $\begin{array}{l}\text { Technological } \\
\text { innovation }\end{array}$ \\
\hline $\mathrm{I} 22$ & & $\begin{array}{l}\text { Funding for } \\
\text { technological } \\
\text { development }\end{array}$ & & $\begin{array}{l}\text { Technological } \\
\text { innovation }\end{array}$ \\
\hline $\mathrm{I} 23$ & $\begin{array}{l}\text { Health and } \\
\text { Environment }\end{array}$ & Green technologies & & $\begin{array}{l}\text { Environmental } \\
\text { and energy crises }\end{array}$ \\
\hline
\end{tabular}




\begin{tabular}{|c|c|c|c|c|}
\hline \multirow[b]{2}{*}{ Index } & \multirow[b]{2}{*}{ Pillar } & \multirow[b]{2}{*}{ Indicators } & \multicolumn{2}{|l|}{ Criteria } \\
\hline & & & $\begin{array}{l}\text { Critical factor for } \\
\text { quality competitiveness }\end{array}$ & Global trend \\
\hline $\mathrm{I} 24$ & & $\begin{array}{l}\text { Sustainable } \\
\text { development }\end{array}$ & $\begin{array}{l}\text { Continuous } \\
\text { improvement }\end{array}$ & \\
\hline $\mathrm{I} 25$ & & Pollution problems & & $\begin{array}{l}\text { Environmental } \\
\text { and energy crises }\end{array}$ \\
\hline I 26 & & Environmental laws & & $\begin{array}{l}\text { Environmental } \\
\text { and energy crises }\end{array}$ \\
\hline
\end{tabular}

Of the total of 51 indicators selected from the WEF and the IMD, those that overlap in meaning were combined, resulting in a total of 35 indicators for the NQCI. They were labelled afresh to suit the purpose of this study as long as the new designations remain in line with the existing terminology (See Table 5).

Table 5 - Creating NQCI Indicators Using WEF and IMD Materials

\begin{tabular}{llll}
\hline $\begin{array}{l}\text { NQCI } \\
\text { Indicator }\end{array}$ & $\begin{array}{l}\text { WEF } \\
\text { Indicator }\end{array}$ & $\begin{array}{l}\text { IMD } \\
\text { Indicator }\end{array}$ & Meaning of NQCI Indicator \\
\hline N1 & W1 & I1 & Corporate ethics \\
N2 & W2 & I2, I3 & Basic infrastructure \\
N3 & W3 & I4 & Education system \\
N4 & W4 & & Strength of competitiveness in domestic market \\
N5 & W5 & I6 & Degree of customer orientation \\
N6 & W6 & & Buyer maturity \\
N7 & W7 & I7 & Labor relations \\
N8 & W8 & I8 & Hiring flexibility \\
N9 & W9 & I9 & Financial maturity \\
N10 & W10 & I10 & Venture capitalism \\
N11 & W11 & & New technology availability \\
N12 & W12 & I11 & Capabilities to accept technology \\
N13 & W13 & & Size of subcontractors \\
N14 & W14 & & Quality of subcontractors \\
N15 & W15 & & Unique competitiveness \\
N16 & W16 & & Global logistics management \\
N17 & W17 & & Production process maturity \\
N18 & W18 & & Marketing expertise \\
N19 & W19 & I12 & Innovation capability \\
& & &
\end{tabular}




\begin{tabular}{|c|c|c|c|}
\hline $\begin{array}{l}\text { NQCI } \\
\text { Indicator }\end{array}$ & $\begin{array}{l}\text { WEF } \\
\text { Indicator }\end{array}$ & $\begin{array}{l}\text { IMD } \\
\text { Indicator }\end{array}$ & Meaning of NQCI Indicator \\
\hline $\mathrm{N} 20$ & W20 & & Level of competency in science \& engineering research institutes \\
\hline $\mathrm{N} 21$ & W21 & $\mathrm{I} 13, \mathrm{I} 14$ & Investment in $R \& D$ \\
\hline $\mathrm{N} 22$ & W22 & $\mathrm{I} 15$ & Industry-academia collaboration and technology transfers \\
\hline $\mathrm{N} 23$ & W23 & & Governmental purchases of cutting-edge products \\
\hline $\mathrm{N} 24$ & W24 & I5 & Availability of science \& technology personnel \\
\hline $\mathrm{N} 25$ & W25 & I16 & Patents \\
\hline $\mathrm{N} 26$ & & $\mathrm{I} 17$ & Development of human resources \\
\hline $\mathrm{N} 27$ & & $\mathrm{I} 18$ & Corporate social responsibility \\
\hline $\mathrm{N} 28$ & & $\mathrm{I} 19$ & Telecommunications technology \\
\hline $\mathrm{N} 29$ & & $\mathrm{I} 20$ & Capability to develop and utilize technology \\
\hline $\mathrm{N} 30$ & & $\mathrm{I} 21$ & Technological assets \\
\hline N31 & & $\mathrm{I} 22$ & Proficiency of technical work force \\
\hline $\mathrm{N} 32$ & & $\mathrm{I} 23$ & Green technology \\
\hline N33 & & $\mathrm{I} 24$ & Capability for sustainable development \\
\hline N34 & & $\mathrm{I} 25$ & Capability to mitigate pollution \\
\hline N35 & & $\mathrm{I} 26$ & Business-friendly environmental regulations \\
\hline
\end{tabular}

\subsection{Statistical verification}

In this study, the 58 countries evaluated by the IMD were subjected to a statistical analysis. All 58 countries were included in the 130 countries evaluated by the WEF. Thus, they were deemed appropriate for this study, which utilizes both WEF and IMD data. Factor analysis was conducted to explore potential indicators/factors that could explain the correlation between the evaluation items. Based on the analysis, weighted values were established to calculate the NQCI value.

\section{Creating indicators}

In the descriptive statistics conducted for this study, the indicators selected from the WEF and IMD were used as the indicators for devising the NQCI. Because the WEF uses a seven-point scale while the IMD uses a 10-point scale, the data were first standardized by using descriptive statistics and the mean values acquired from the standardization were used as new indicators values. Considering that the final quality competitiveness indices have values ranging between 0 and 100, the indicators were converted, starting from the data preparation, so that the values would be between 0 and 100. This process simplified identifying a country's standing in terms of national quality competitiveness. 


\section{Factor analysis and distance matrix}

In this study, factor analysis was conducted as a test preceding the cluster analysis that later grouped the selected indicators into sub-groups with similar properties. Principal factor method by a year was used for factor analysis with the combined indicators. When considering with an Eigen value greater than 1 and a cumulative value ranging between 0.7 and 0.9 , ' 5 ' was deemed appropriate for the number of factors.

Using the results of factor analysis, the factor loading was obtained; from the factor loading matrix, the distance matrix between the indicators was obtained using the values representing the same factors. This distance matrix was used as the input data for the cluster analysis.

\section{Cluster analysis}

Cluster analysis is a technique used to categorize indicators with a variety of properties into homogeneous groups based on their similarities (Scott and Knott, 1974). This method can be assigned to clusters that are composed of similarly characterized indicators. This study utilized a hierarchical cluster analysis, Ward's minimum variance method (Ward Jr, 1963). As shown in Figure 3, when semi-partial $R^{2}$ values set 0.1 as a criteria for categorization, the 35 indicators are categorized into four clusters. Because indicator N9 from Cluster 1 has been excluded from the survey items since 2010, this study uses the 34 indicators for the analysis excluding N9.

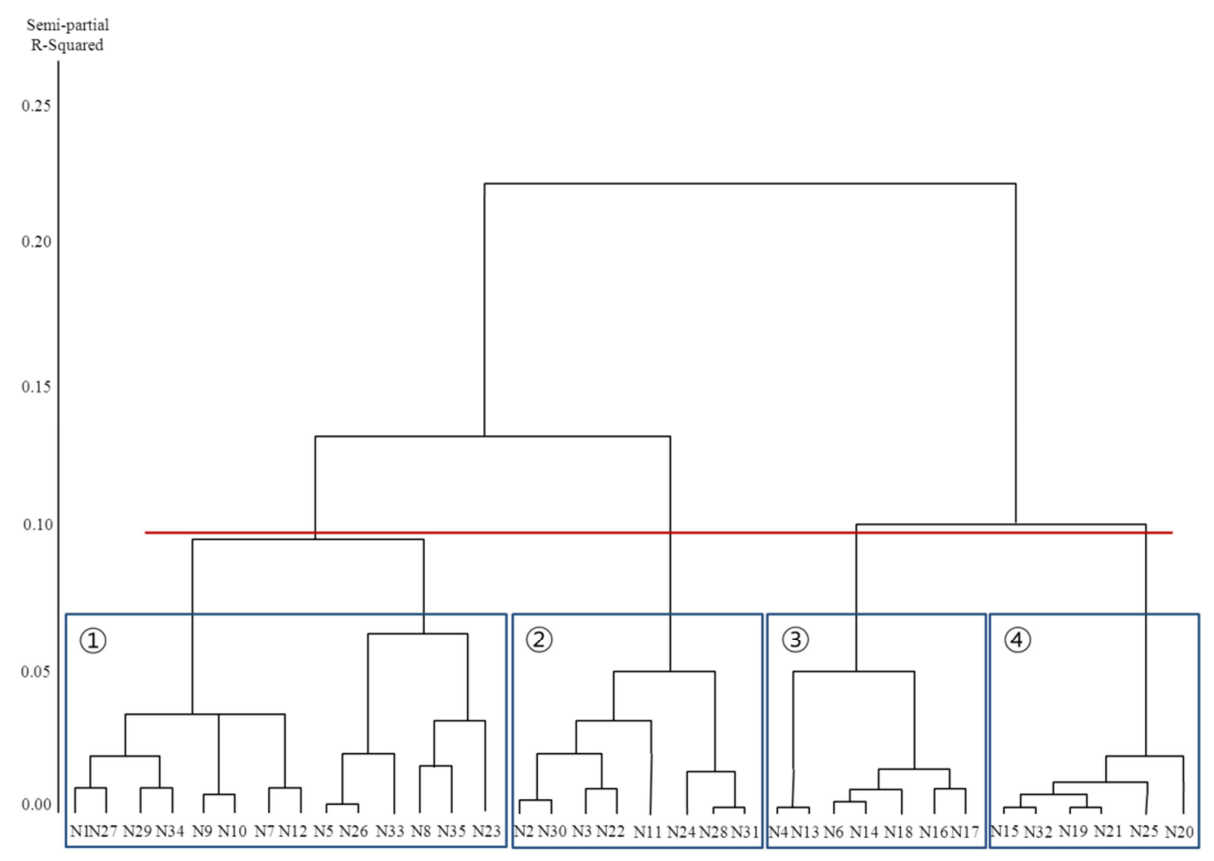

Figure 3 - Cluster analysis results using Ward's method 


\section{Identification of four quality-competitiveness capabilities}

Based on the cluster analysis results (Table 6), an expert consensus method was used to draw four perspectives of quality competitiveness that were believed to best represent each cluster. The perspectives are sustainable capability, basic infrastructure capability, primary activity capability, and innovation capability.

Table 6 - Four Clusters and their Indicators (Indicators)

\begin{tabular}{|c|c|c|}
\hline Cluster & Indicators & \\
\hline \multirow{9}{*}{$\begin{array}{l}\text { C1. } \\
\text { Sustainable } \\
\text { Capability }\end{array}$} & N1 (Corporate ethics) & N26 (Human resources development) \\
\hline & \multirow{2}{*}{$\begin{array}{l}\text { N5 (Degree of customer } \\
\text { orientation) }\end{array}$} & N27 (Corporate social responsibility) \\
\hline & & \multirow{2}{*}{$\begin{array}{l}\text { N29 (Capability to develop and utilize } \\
\text { technology) }\end{array}$} \\
\hline & N7 (Labour relations) & \\
\hline & N8 (Hiring flexibility) & N33 (Capability for sustainable \\
\hline & N10 (Venture capitalism) & development) \\
\hline & \multirow{2}{*}{$\begin{array}{l}\text { N12 (Capabilities to accept } \\
\text { technology) }\end{array}$} & N34 (Capability to mitigate pollution) \\
\hline & & \multirow{2}{*}{ N35 (Business-friendly regulations) } \\
\hline & $\begin{array}{l}\text { N23 (Governmental purchases of } \\
\text { cutting-edge products) }\end{array}$ & \\
\hline \multirow{5}{*}{$\begin{array}{l}\mathrm{C} 2 . \\
\text { Basic } \\
\text { Infrastructure } \\
\text { Capability }\end{array}$} & N2 (Basic infrastructure) & \multirow{2}{*}{$\begin{array}{l}\text { N24 (Availability of science } \\
\& \text { technology personnel) }\end{array}$} \\
\hline & N3 (Education system) & \\
\hline & N11 (New technology availability) & $\begin{array}{l}\text { N28 (Telecommunications } \\
\text { technology) }\end{array}$ \\
\hline & \multirow{2}{*}{$\begin{array}{l}\text { N22 (Industry-academia } \\
\text { collaboration and technology } \\
\text { transfers) }\end{array}$} & N30 (Technological assets) \\
\hline & & $\begin{array}{l}\text { N31 (Proficiency of } \\
\text { technical work force) }\end{array}$ \\
\hline \multirow{4}{*}{$\begin{array}{l}\text { C3. } \\
\text { Primary } \\
\text { Activity } \\
\text { Capability }\end{array}$} & \multirow{2}{*}{$\begin{array}{l}\text { N4 (Strength of competitiveness } \\
\text { in domestic market) }\end{array}$} & N14 (Quality of subcontractors) \\
\hline & & N16 (Global logistics management) \\
\hline & N6 (Buyer maturity) & N17 (Production process maturity) \\
\hline & N13 (Size of subcontractors) & N18 (Marketing expertise) \\
\hline \multirow{3}{*}{$\begin{array}{l}\text { C4. } \\
\text { Innovation } \\
\text { Capability }\end{array}$} & N15 (Unique competitiveness) & N21 (Technological assets) \\
\hline & N19 (Innovation) & N25 (Patents) \\
\hline & $\begin{array}{l}\text { N20 (Level of competency in } \\
\text { science \& engineering } \\
\text { research institutes) }\end{array}$ & N32 (Green technology) \\
\hline
\end{tabular}

First, sustainable capability is operationally defined as a company's competency to pursue sustainability while taking into account economic, environmental, and social issues and achieving a balance. Second, basic infrastructure capability is defined operationally as a company's degree of utilization of the basic components (e.g., education/training, technology, human resources) that are indispensable for their quality control. Third, the operational definition of 
primary activity capability is a company's capability to engage in activities that contribute to the creation of added value in products and services that can be transferred directly to customers. This type of capability includes inbound logistics, operations, outbound logistics, marketing and sales, and services. Lastly, innovation capability is defined as how a company develops and manages the factors such as unique competitiveness, investment in $R \& D$, patent ownership, and green technology that can help facilitate its innovation.

\subsection{Identification of a quality competitiveness index}

After ensuring the validity of the four perspectives and the selected indicators, the NQCI value was calculated for this study. Principal component analysis (PCA) was carried out to identify the single element that best describes four new indicators (i.e., C1, C2, C3, and C4) which represent the clusters. This was done by obtaining the average value of the indicators in each cluster.

- $\mathrm{C} 1$ (Sustainable Capability $)=(\mathrm{X} 1+\mathrm{X} 5+\mathrm{X} 7+\mathrm{X} 8+\mathrm{X} 10+\mathrm{X} 12+\mathrm{X} 23+$ $\mathrm{X} 26+\mathrm{X} 27+\mathrm{X} 29+\mathrm{X} 33+\mathrm{X} 34+\mathrm{X} 35) / 13$

- $\mathrm{C} 2$ (Basic Infrastructure Capability $)=(\mathrm{X} 2+\mathrm{X} 3+\mathrm{X} 11+\mathrm{X} 22+\mathrm{X} 24+$ $\mathrm{X} 28+\mathrm{X} 30+\mathrm{X} 31) / 8$

- $\mathrm{C} 3$ (Primary Activity Capability $)=(\mathrm{X} 4+\mathrm{X} 6+\mathrm{X} 13+\mathrm{X} 14+\mathrm{X} 16+\mathrm{X} 17+\mathrm{X} 18) / 7$

- $\mathrm{C} 4$ (Innovation Capability $)=(\mathrm{X} 15+\mathrm{X} 19+\mathrm{X} 20+\mathrm{X} 21+\mathrm{X} 25+\mathrm{X} 32) / 6$

As in the earlier factor analysis, ' 1 ' was deemed appropriate as the number for the principal component when using criteria with an Eigen value greater than 1 and a cumulative value ranging from 0.7 to 0.9 . Thus, the Eigenvector of the first principal component was used as the weighted value for calculating the NQCI value for each year (Table 7). Using the average of the year-specific weighted values, the final weighted value was calculated.

Table 7 - Weighted Value obtained through the Principal Component Analysis

\begin{tabular}{lllll}
\hline Year & C1 & C2 & C3 & C4 \\
\hline 2005 & 0.4969 & 0.4989 & 0.5065 & 0.4976 \\
2007 & 0.4890 & 0.5068 & 0.5000 & 0.5040 \\
2008 & 0.4908 & 0.5118 & 0.4970 & 0.5002 \\
2009 & 0.4962 & 0.5102 & 0.4960 & 0.4975 \\
2010 & 0.4964 & 0.5051 & 0.4918 & 0.5065 \\
Weighted Value & 0.4939 & 0.5065 & 0.4983 & 0.5012
\end{tabular}


To ensure that the NQCI has a value between 0 and 100, the weighted value was divided by 2 and then rounded off to four decimal places. The adjusted weighted value is as follows:

- The NQCI $=0.247 \times \mathrm{C} 1+0.253 \times \mathrm{C} 2+0.249 \times \mathrm{C} 3+0.251 \times \mathrm{C} 4$

\section{THE EMPIRICAL ANALYSIS OF THE NQCI}

To conduct an empirical analysis of the NQCI, a total of 18 countries were selected from the 58 target countries mentioned earlier. For this selection, G20 member states were used as the reference, except for the EU, which is not a country, and Saudi Arabia, which is not included in the IMD's 58 countries (Table 8). The NQCI was applied to the 18 countries for each year concerned.

Table 8 - The NQCI and Ranking of 18 Countries (by Year)

\begin{tabular}{|c|c|c|c|c|c|c|c|c|c|c|}
\hline \multirow{2}{*}{ Country } & \multicolumn{5}{|c|}{ NQCI } & \multicolumn{5}{|c|}{ NQCI Ranking } \\
\hline & 2005 & 2007 & 2008 & 2009 & 2010 & 2005 & 2007 & 2008 & 2009 & 2010 \\
\hline Argentina & 49 & 49 & 48 & 48 & 49 & 53 & 56 & 57 & 56 & 51 \\
\hline Australia & 67 & 68 & 68 & 67 & 66 & 22 & 22 & 21 & 22 & 24 \\
\hline Brazil & 54 & 55 & 56 & 57 & 56 & 42 & 43 & 42 & 36 & 38 \\
\hline Canada & 72 & 72 & 71 & 70 & 71 & 13 & 15 & 15 & 14 & 12 \\
\hline China & 53 & 55 & 57 & 57 & 58 & 46 & 44 & 36 & 34 & 33 \\
\hline France & 71 & 71 & 71 & 69 & 69 & 14 & 18 & 14 & 16 & 17 \\
\hline Germany & 76 & 77 & 75 & 75 & 75 & 6 & 7 & 8 & 7 & 5 \\
\hline India & 62 & 62 & 61 & 61 & 59 & 27 & 25 & 29 & 28 & 31 \\
\hline Indonesia & 49 & 57 & 56 & 55 & 57 & 54 & 40 & 41 & 41 & 37 \\
\hline Italy & 55 & 56 & 56 & 55 & 56 & 40 & 41 & 39 & 42 & 41 \\
\hline Japan & 79 & 79 & 77 & 78 & 78 & 3 & 2 & 3 & 2 & 2 \\
\hline Korea, Rep & 68 & 74 & 68 & 67 & 67 & 20 & 11 & 18 & 19 & 22 \\
\hline Mexico & 49 & 52 & 50 & 51 & 49 & 55 & 50 & 53 & 51 & 53 \\
\hline Russian Federation & 51 & 52 & 53 & 51 & 48 & 50 & 51 & 52 & 52 & 56 \\
\hline South Africa & 58 & 57 & 57 & 56 & 55 & 31 & 39 & 38 & 38 & 42 \\
\hline Turkey & 56 & 57 & 55 & 56 & 56 & 38 & 38 & 44 & 40 & 39 \\
\hline United Kingdom & 70 & 71 & 69 & 69 & 69 & 17 & 19 & 19 & 18 & 18 \\
\hline United States & 82 & 78 & 79 & 77 & 75 & 1 & 3 & 2 & 5 & 6 \\
\hline
\end{tabular}

In this study, the results of applying the NQCI to the countries were used to identify the differentiations between high and low ranked groups. Based on these 
analyses, our results not only provide an implication for quality policies at the national level to the referenced 18 countries but also to other nations. Based on Table 8 , primary activity capability and innovation capability have a relatively higher influence on national quality competitiveness for countries ranked higher in the NQCI. This indicates that the higher-ranked countries need active corporate efforts as well as governmental quality policies and intervention. For example, the government has supported the establishment of the inter-business networks to create industrial clusters that help increase the efficiency of primary corporate activities.

For the countries that ranked lower in the NQCI, it is important that the government plays a central role in strengthening quality competitiveness and implementing the industrial modernization steps. This fact could be confirmed by comparing two lower ranked countries, China and Russian Federation.

In China the government has begun an national effort to strictly manage quality by establishing a governmental institutions such as the General Administration of Quality Supervision and the Inspection and Quarantine of the People's Republic of China (Pompeo, 2007). Consequently, China improved its NQCI standing from being $46^{\text {th }}$ in 2005 to $33^{\text {rd }}$ in 2010 .

Whereas, Russian Federation relied only on the energy sector, such as, oil, natural gas, metals and timber, and neglected to improve their competitiveness in its manufacturing and service sectors (Ahrend, 2004; Mills, Dukeov and Fey, 2007). As a result, Russian Federation slid in rank from $50^{\text {th }}$ in 2005 to $56^{\text {th }}$ in 2010.

Next, national competitiveness rankings were compared with rankings in the NQCI. For easy comparison, countries included in both NQCI and IMD were compared.

The results show that the majority of the countries are ranked similarly in both indices during 2005 to 2010, except for 2006. The Spearman rank correlation coefficient was calculated between the indices of all 18 countries for each year concerned. The values obtained were 0.896 (2005 year), 0.806 (2007 year), 0.879 (2008 year), 0.922 (2009 year), and 0.888 (2010 year), showing a high statistical correlation which represents a mutually compensating relationship. Therefore, improvement of NQCI is closely related to improvement of national competitiveness.

\section{CONCLUSION}

This study developed a competitive index specializes in national quality. An attempt to devise this type of index has never been tried elsewhere. This index provides a theoretical value by statistically investigating the validity and reliability of the data. These findings also help government to establish a more concrete quality policies through quantified indices. 
First, this study categorized the factors considered for quality competitiveness into four different perspectives using statistical techniques. Policy makers will be able to initiate new policy projects by apprehending the pros and cons of quality competitiveness using these perspectives. Second, in the process of applying the NQCI, we have discovered a difference in quality policies between high ranked and low ranked countries. Therefore, it indicates that a country willing to improve national quality should benchmark quality policies of countries at a similar level. Lastly, through analysing the correlation between NQCI and national competitiveness from IMD, NQCI was found to be an important factor that guides to higher national competitiveness.

The limitations of this study include a lack of consistency in evidence, as demonstrated in the results. That is to say, the evidence failed to show consistently that the NQCI is capable of operating as an early indicator of countries' national competitiveness. This is attributable to the fact that the NQCI was "borrowed" from existing indices to ensure obtainability instead of developing new index. For the same reason, the application of and comparison via the NQCI is limited to the target countries of the WEF and IMD. Therefore, future research may need to ensure that the NQCI leads national competitiveness indices by rearranging existing indices, by adjusting the weighted values, or by conducting research on the development of new index.

\section{ACKNOWLEGEMENT}

This work was supported by the National Research Foundation of Korea Grant funded by the Korean Government (NRF-2012-2012S1A3A2033474). 


\section{REFERENCES}

Ahrend, R., 2004. Accounting for Russia's post-crisis growth. OECD Economics Department Working Papers No.404. France: OECD Publishing.

Black, S. A. and Porter, L. J., 1996. Identification of the Critical Factors of TQM*. Decision Sciences, 27(1), p.1-21.

Blackiston, G. H., 1996. Juran Institute: a barometer of trends in quality management. National Productivity Review, 16(1), p.15-23.

Buzzell, R. D. and Gale, B. T., 1987. The PIMS principles: Linking strategy to performance. New York: Free Press.

Cho, D. S. and Moon, H. C., 2005. National competitiveness: Implications for different groups and strategies. International Journal of Global Business and Competitiveness, 1(1), p.1-11.

ERNST\&YOUNG, 2010. Tracking global trends. ERNST\&YOUNG.

Feigenbaum, A., 1982. Quality and business growth today. Quality Progress, 15(11), p.22-25.

Fingar, C. T., 2009. Global trends 2025: A transformed world. Washington, DC: DIANE Publishing.

Garelli, S., 2006. Competitiveness of nations: the fundamentals. In: IMD World Competitiveness Yearbook. Switzerland: IMD.

Gronroos, C., 1990. Service management and marketing: managing the moments of truth in service competition. Lexington, Mass: Lexington Books.

Juran, J. M., 1988. Juran on planning for quality. New York: Free press.

Lall, S., 2001. Competitiveness indices and developing countries: an economic evaluation of the Global Competitiveness Report. World Development, 29(9), p.1501-1525.

Mehra, S. and Agrawal, S. P., 2003. Total quality as a new global competitive strategy. International Journal of Quality \& Reliability Management, 20(9), p.1009-1025.

Mills, T., Dukeov, I. and Fey, C. F., 2007. Russian Competitiveness in the Global Economy. Journal of East West Business, 13(4), p.97.

Pompeo, J., 2007. Living inside China's quality revolution. Quality progress, 40(8), p.30.

Porter, L. J. and Parker, A. J., 1993. Total quality management-the critical success factors. Total quality management, 4(1), pp.13-22.

Porter, M. E., 1998. Competitive advantage: creating and sustaining superior performance: with a new introduction. New York: Free Press. 
Reeves, C. A. and Bednar, D. A., 1994. Defining quality: alternatives and implications. The Academy of Management Review, 19(3), pp.419-445.

Saraph, J. V., Benson, P. G. and Schroeder, R. G., 1989. An instrument for measuring the critical factors of quality management. Decision Sciences, 20(4), pp.810-829.

Schwab, K., 2009. The Global Competitiveness Report 2009-2010. Geneva: World Economic Forum.

Schwab, K., 2010. The Global Competitiveness Report 2010-2011. Geneva: World Economic Forum.

Scott, A. and Knott, M., 1974. A cluster analysis method for grouping means in the analysis of variance. Biometrics, 30(3), pp.507-512.

Tyson, L. D. A., 1993. Who's bashing whom?: trade conflict in high-technology industries. Washington, DC: Institute for International Economics.

Ward Jr, J. H., 1963. Hierarchical grouping to optimize an objective function.. Journal of the American statistical association, 58(301), pp.236-244.

\section{ABOUT THE AUTHORS}

Insu Cho, Ph.D. student, Department of Information and Industrial Engineering, Yonsei University, Republic of Korea, e-mail: bluefin84@yonsei.ac.kr.

Kiwon Lee, Master student, Department of Information and Industrial Engineering, Yonsei University, Republic of Korea, e-mail: kiwon714@yonsei.ac.kr.

Heejun Park, Corresponding author, Professor, Department of Information and Industrial Engineering, Yonsei University, Republic of Korea, e-mail: h.park@yonsei.ac.kr, Telephone: +82 22123 5717, fax: +82 23647807.

Myungho Park, Ph.D. student, Graduate School of Engineering, Yonsei University, Republic of Korea, e-mail: yami_27@hanmail.net.

Joseph Kichul Kim, Ph.D. student, Department of Management, Oklahoma State University, United States of America, e-mail: Jimjk@ostatemail.okstate.edu. 